
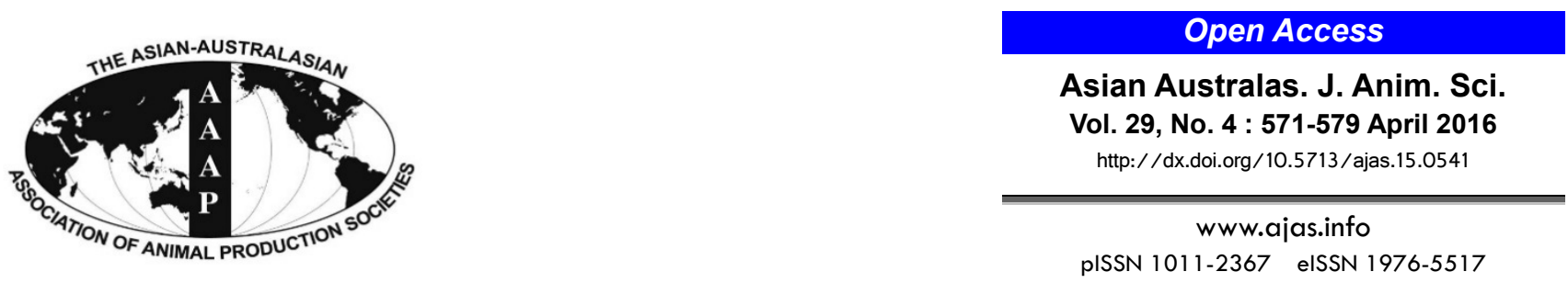

\title{
Development of a Novel, Anti-idiotypic Monoclonal Anti-prolactin Antibody That Mimics the Physiological Functions of Prolactin
}

\author{
Meng Wang, Dian-Cai Zhang ${ }^{1}$, Shen-Tian Wang, and Ming-Long $\mathrm{Li}^{2}$,* \\ Endocrine Department, Yidu Central Hospital of Weifang, Weifang 262500, China
}

\begin{abstract}
In this work, we prepared a panel of monoclonal anti-idiotypic antibodies to ovine prolactin (oPRL) by the hybridoma technique. Among these antibodies, one anti-idotypic antibody (designated B7) was chosen for further characterization by a series of experiments. We first demonstrated that B7 behaved as a typical Ab2 $\beta$ based on a series of enzyme-linked immunosorbent assays. Subsequently, the results of a competitive receptor-binding assay confirmed that B7 could specifically bind to the prolactin receptor (PRLR) expressed on target cells. Finally, we examined its biological activities in CHO-PRLR and Nb2 cells and observed that B7 could activate Janus kinase 2-signal transducer and activator of transcription signalling in CHO-PRLR and Nb2 cells and induce BaF3 proliferation. The present study suggests that i) B7 can serve as a PRLR agonist or PRL mimic and has potential applications in regulating mammary gland development, milk production and maintenance of lactation in domestic animals and ii) B7 may be a biological reagent that can be used to explore the mechanism of PRLR-mediated intracellular signalling. (Key Words: Prolactin, Antiidotypic Antibody, Signal Transduction)
\end{abstract}

\section{INTRODUCTION}

Prolactin (PRL) is a polypeptide hormone that is synthesized in the pituitary gland, consists of 199 amino acids with a molecular mass of $23 \mathrm{KD}$, and has more functions than all other pituitary hormones combined (Freeman et al., 2000). The initial step in the action of PRL, similar to all other hormones, is binding to the extracellular domain of prolactin receptor (PRLR). PRL binding to PRLR leads to the phosphorylation of the associated Janus kinase 2 (JAK2), which, in turn, phosphorylates multiple signalling pathways, e.g., signal transducer and activator of transcription (STAT), phosphatidylinositol 3-kinase (PI3K), extracellular-signal regulated kinase (ERK1/2) (Bole-Feysot et al., 1998). These signalling pathways act together to contribute to the overall actions of PRL.

Prolactin has more than 300 separate functions in

\footnotetext{
* Corresponding Author: Ming-Long Li. Tel: +86-0536-3275623, Fax:+86-0536-3275623, E-mail: MingLongLi2015@163.com

${ }^{1}$ Dermatological Department, Yidu Central Hospital of Weifang, Weifang 262500, China.

${ }^{2}$ China Shandong Provincial Hospital, Jinan250000, China.

Submitted Jun. 26, 2015; Revised Jul. 30, 2015; Accepted Sept. 3, 2015
}

vertebrates. The roles of prolactin in domestic animals has been extensively studied, which reveal that prolactin plays an important role in mammary gland development (McLaughlin et al., 1997; Farmer et al., 2000), milk production (Bar-Pelled et al., 1995; Dybus, 2002; Ramos et al., 2009), and maintenance of lactation (Knight, 2001; He et al., 2006; Tygesen et al., 2008). It has also been reported that prolactin is required for follicular growth in mares, sheep and sow (Reddy et al., 2005). In addition, prolactin also plays an essential role in metabolism, regulation of the immune system, reproductive behavior, and pancreatic development (Freeman et al., 2000). Because prolactin has important physiological roles and functions, scientists have been investigating possible PRL mimics. During the past few decades, the use of anti-PRLR antibodies as PRL mimics has been densely reported. One approach is the use of antibodies raised against PRLR as PRL mimics. Djiane et al. (1981; 1985) initially reported that polyclonal antiPRLR antibodies were capable of mimicking prolactin action on casein gene expression, DNA synthesis and tumour mammary gland explants. Since then, several similar studies have reported that some special anti-PRLR antibodies could exert PRL-like biological effects (Djiane et 
al., 1981; Okamura et al., 1989; Rui et al., 1994); another approach has been to prepare anti-idiotypic antibodies to PRL, which is based on the Network Theory of Jerne (1974). Amit et al. (1986) reported that polyclonal antiidiotypic antibodies to PRL could recognize PRLR, which suggested that common epitopes are shared by PRL and anti-idiotypic antibodies to PRL. To the best of our knowledge, this study is the only one that reported the use of anti-idiotypic antibody as PRL analogues; however, to date, whether anti-idiotypic antibody can mimic PRL's functions remains unclear.

In the present study, we prepared a panel of monoclonal anti-idiotypic antibodies against PRL, and we have determined that one antibody, termed B7, could trigger intracellular signalling (JAK2-STAT5) in CHO-PRLR and $\mathrm{Nb} 2$ cells. In addition, $\mathrm{B} 7$ also can induce $\mathrm{BaF} 3$ proliferation. The current observations suggest that i) the anti-idiotypic approach is suitable to generate PRL mimic, and ii) an anti-idiotypic antibody to PRL (such as B7) has potential applications in animal production. Furthermore, the current study also implies that the anti-idiotypic antibody (B7) may be a useful reagent to explore the mechanism of PRLR activation because B7 could activate PRLR-mediated intracellular signalling.

\section{MATERIALS AND METHODS}

Anti-total JAK2 and anti-phospho-JAK2, anti-total STAT-5 and anti-phospho-STAT5 were purchased from Cell Signalling Technology (Boston, MA, USA). Horseradish peroxidase (HRP)-conjugated goat anti-rabbit and antimouse antibodies were purchased from Sigma (St. Louis, MO, USA). Ovine prolactin (oPRL) was purchased from Hua Sheng Medical and Biological Laboratories Co., Ltd (Jinan, China). ${ }^{125} \mathrm{I}$-oPRLwas prepared using chloramine $\mathrm{T}$ according to published procedures. The ImmunoPure Fab Preparation kit and Enhanced chemiluminescence (ECL) were obtained from Pierce (Rockford, IL, USA). Protein Assay Kit (BCA) kit and Cell Lysis Buffer were from Bi yuntian Biology Technological Institute (Shanghai, China). The cell culture medium and foetal calf serum (FCS) were obtained from Gibco (Grand Island, NY, USA). Unless stated otherwise, all other reagents were from SigmaAldrich (St. Louis, MO, USA).

$\mathrm{CHO}$ and $\mathrm{Ba} / \mathrm{F} 3$ that were stably transfected with rat PRLR cDNA (termed as Ba/F3-PRLR) that encoded amino acids 1-591 (long form) were prepared and provided by Hualong (Biological Laboratories Co., Ltd., China), and it has been determined that the clone used in this work expressed 6800 receptors per $\mathrm{CHO}$ cell (termed as $\mathrm{CHO}-$ PRLR). CHO-PRLR cells were grown and maintained in F$12 \mathrm{~K}$ medium containing $10 \%$ heat-inactivated foetal bovine serum (FBS), $100 \mathrm{U} / \mathrm{mL}$ penicillin and $100 \mu \mathrm{g} / \mathrm{mL}$ streptomycin. $\mathrm{Nb} 2$ cells were grown and maintained in RPMI-1640 medium containing 10\% FBS, $50 \mathrm{U} / \mathrm{mL}$ penicillin and $50 \mu \mathrm{g} / \mathrm{mL}$ of streptomycin.

\section{Preparation of polyclonal anti-growth hormone antibodies}

Rabbits were injected intradermally at multiple sites with $1 \mathrm{mg}$ oPRL emulsified in Freund's complete adjuvant and received similar booster injections of oPRL in incomplete Freund's adjuvant at two-week intervals. The rabbits were bled weekly after the first booster injection and 1 week after receiving the last injections. After four immunisations, immunized rabbits were shown to generate high-titre sera against oPRL, as determined by enzymelinked immunosorbent assays (ELISA). Immunoglobulin G (IgG) fragments were purified from each rabbit by ammonium sulphate precipitation followed by protein-A affinity chromatography.

\section{Preparation of monoclonal anti-idiotypic antibody to ovine prolactin}

Female BALB/c mice (6 to 8 weeks old) were purchased from the Peking university laboratory animal centre. The mice were immunized intraperitoneally with 0.2 $\mathrm{mg}$ of rabbit anti-oPRL-F(ab') $)_{2}$ emulsified in Freund's complete adjuvant and received similar booster injections of anti-oPRL-F( $\left(\mathrm{ab}^{\prime}\right)_{2}$ emulsified in incomplete Freund's adjuvant at two-week intervals. The animals were immunized four times. Three days after final immunization, splenocytes from mice immunized with anti-oPRL-F(ab') were harvested and fused with sp2/0 myeloma cells at a 5:1 ratio using 50\% (w/v) polyethylene glycol (PEG) 1500. After fusion, the cells were distributed in 96-well plates at $1 \times 10^{5}$ cells per well in the hypoxanthine/aminopterin/ thymidine (HAT) selection medium. The culture supernatants of hybridomas selected on HAT medium were tested by ELISA to determine the presence of antibodies against anti-oPRL-F( $\left(a b^{\prime}\right)_{2}$. Antibody-secreting hybridomas were subcloned four times via limiting dilution, and a number of monoclonal anti-oPRL-F(ab')2 antibodysecreting cell lines were selected for expansion into mass culture and production of ascetic fluids.

\section{Enzyme-linked immunosorbent assays}

To test the rabbit anti-oPRL polyclonal antibodies, 96well plates were coated with $0.1 \mu \mathrm{g}$ per well of oPRL in PBS (PH 7.2) overnight at $4^{\circ} \mathrm{C}$. The plates were subsequently washed four times with PBS in $0.05 \%$ Tween 20 (PBST), blocked with $2.5 \%$ non-fat powder in PBS and incubated with Rabbit antisera diluted to their optimum concentration in PBST. The plates were incubated for $1.5 \mathrm{~h}$ at $37^{\circ} \mathrm{C}$, washed and reincubated with the HRP-conjugated goat anti-rabbit IgG. After $1 \mathrm{~h}$, the plates were washed and 
incubated with the tetramethylbenzidine (TMB) substrate. The results were read at $450 \mathrm{~nm}$ in an automatic ELISA plate reader (Multiskan FC, Thermo Fisher Scientific Inc., Waltham, MA, USA).

To detect the monoclonal anti-idiotypic antibodies to PRL, 96-well plates were coated with purified anti-PRLR $\mathrm{F}\left(\mathrm{ab}^{\prime}\right)_{2}$ fragments or with $\mathrm{F}\left(\mathrm{ab}^{\prime}\right)_{2}$ fragments of control antibodies overnight at $4^{\circ} \mathrm{C}$. The plates were then washed four times with PBS in $0.05 \%$ Tween 20 (PBST), blocked with $2.5 \%$ non-fat powdered in PBS and incubated with the culture supernatants from the hybridomas, and the wells were incubated at $37^{\circ} \mathrm{C}$ for $1 \mathrm{~h}$. After washing, goat antimouse IgG-FC HRP secondary antibody was added, and after $1 \mathrm{~h}$, the plates were washed and incubated with TMB substrate, and the results were read at $450 \mathrm{~nm}$ in an automatic ELISA plate reader (Multiskan FC, Thermo Fisher Scientific Inc., USA).

\section{Fluorescence-activated cell sorting}

CHO-PRLR cells were trypsinised and detached from the plate surface and adjusted to a density of $1 \times 10^{5}$ cells $/ \mathrm{mL}$. The cells were then incubated with $100 \mu \mathrm{L}$ in either a negative control medium or in one of the positive hybridoma supernatants for $1 \mathrm{~h}$ at $4^{\circ} \mathrm{C}$. After three washes with PBST, cells were fixed and stained with FITC-labelled goat-anti-mouse IgG. After staining, the cells were incubated with FITC-labelled goat anti-mouse $\operatorname{IgG}$ for $1 \mathrm{~h}$ at $4{ }^{\circ} \mathrm{C}$ in the dark. After incubation, the cells were washed and resuspended in $0.5 \mathrm{~mL}$ FACS buffer. All flow cytometric analysis was conducted on FACS Calibur cytometer (Becton Dickenson, New York, NJ, USA). The data were analysed using the Cell Quest software.

\section{Competitive enzyme-linked immunosorbent assay}

Competitive ELISAs were performed according to method of Lan et al. (2015). For the competition studies, ELISA plates were coated with $0.5 \mu \mathrm{g}$ of $\mathrm{F}(\mathrm{ab})_{2}$ fragments of Mab2s or control antibody overnight. The next morning, the plates were washed and blocked as described above. Then, a constant amount of rabbit anti-PRL antibody (Ab1, $1 \mathrm{mg} / \mathrm{mL}$ ) was mixed with different dilutions of PRL and incubated for $1 \mathrm{~h}$ at $37^{\circ} \mathrm{C}$ prior to application of the blocked ELISA plate. The plates were washed again, and goat antimouse IgG (Fc fragment-specific)-HRP secondary antibody was added to the wells for $1 \mathrm{~h}$ at $37^{\circ} \mathrm{C}$. After incubation for $1 \mathrm{~h}$, the plates were washed and incubated with TMB substrate; results were read at $450 \mathrm{~nm}$ in an automatic ELISA plate reader (Multiskan FC, Thermo Fisher Scientific Inc., USA).

In addition, a similar competitive ELISA was performed. The ELISA plates were coated with $0.5 \mu \mathrm{g} F(\mathrm{ab}$ ')2 fragments of rabbit anti-PRLR antibodies overnight. Then, a constant amount of Mab2s was mixed with different dilutions of PRL and incubated for $1 \mathrm{~h}$ at $37^{\circ} \mathrm{C}$ prior to application to the blocked ELISA plate. The subsequent treatments were performed as described as above.

\section{Competitive receptor-binding assay}

CHO-PRLR cells were cultured in serum-free F-12K medium containing $1 \%$ bovine serum albumin for $12 \mathrm{~h}$. The cells were subsequently washed and incubated with 125IPRL $\quad(5,000 \quad \mathrm{CPM} /$ well $)$ together with increasing concentrations of unlabelled PRL and Mab2s or isotypematched control antibody for $2 \mathrm{~h}$. After the incubation, the cells were washed and detached from the plate. The cells were then counted in a gamma counter. The non-specific binding was determined in the presence of $5 \mu \mathrm{g}$ unlabelled PRL.

\section{Western-blot analysis}

CHO-PRLR and $\mathrm{Nb} 2$ cells were cultured in six-well plates as described as above. The cells were cultured in serum-free medium for $10 \mathrm{~h}$ prior to the experimental treatments. For the dose-dependent experiments, serumstarved $\mathrm{CHO}-\mathrm{PRLR}$ and $\mathrm{Nb} 2$ cells were stimulated with the different concentration of $\mathrm{B} 7$ for the indicated time. For the time-course experiment, serum-starved CHO-PRLR and $\mathrm{Nb} 2$ cells were stimulated with the indicated concentration of B7 for different times. Unless otherwise noted, all treatments were performed at $37^{\circ} \mathrm{C}$. At the end of the treatment, cells were solubilized in lysis buffer on ice for 30 min before centrifugation at $12,000 \times \mathrm{g}$ for $10 \mathrm{~min}$. The resulting supernatants were collected and concentrated by ultrafiltration. Samples were lysed directly in sodium dodecyl sulfate-polyacrylamide gel electrophoresis (SDSPAGE) sample buffer and boiled for $5 \mathrm{~min}$, and the protein concentration was determined by BCA Protein Assay according to manufacturer's instructions. Samples $(60 \mu \mathrm{g}$ protein per lane) were subjected to SDS-PAGE, transferred to polyvinylidene fluoride (PVDF) membranes. The membranes were washed and blocked with 5\% non-fat milk for nonspecific binding for $1 \mathrm{~h}$ at $37^{\circ} \mathrm{C}$. After three washes, the membranes were incubated with the primary antibodies (anti-phospho-JAK2 anti-phospho-STAT5) according to the manufacturer's protocols. Following three washes, the membranes were incubated with HRP-conjugated goat antirabbit IgG antibody (secondary antibody) for $1 \mathrm{~h}$ at $37^{\circ} \mathrm{C}$. After three final washes, the blots were then developed using the ECL Plus chemiluminescent detection system according to the manufacturer's instructions. After ECL detection, the membranes were stripped of primary and secondary antibodies using the Restore Western Blot Stripping Buffer according to the manufacturer's instructions, and the blots were subsequently probed with antibodies against total JAK2 and total STAT5. 


\section{Cell proliferation assay}

The $\left[{ }^{3} \mathrm{H}\right]$ thymidine incorporation assay was performed according to the method of (Clevenger et al., 1994). Briefly, $\mathrm{Nb} 2$ or $\mathrm{Ba} / \mathrm{F} 3-P R L R$ cells were grown and maintained in RPMI-1640 medium containing 10\% FBS, $50 \mathrm{U} / \mathrm{mL}$ penicillin, and $50 \mu \mathrm{g} / \mathrm{mL}$ of streptomycin for $24 \mathrm{~h}$. After washing with PBS, the cell suspensions were then prepared. The cell suspensions were added to the wells of 96-well round-bottomed tissue culture plates in a volume of $100 \mu \mathrm{L}$ $\left(1 \times 10^{6}\right.$ cells $\left./ \mathrm{mL}\right)$, and the cells were stimulated with the indicated concentrations of PRL, Mab2s or control antibody in a final volume of $0.2 \mathrm{~mL}$ for $24 \mathrm{~h}$ at $37^{\circ} \mathrm{C}$. Ligandstimulated $\mathrm{Nb} 2$ or $\mathrm{Ba} / \mathrm{F} 3-\mathrm{PRLR}$ cells were labelled for $4 \mathrm{~h}$ with $0.5 \mu \mathrm{Ci}$ of $\left[{ }^{3} \mathrm{H}\right]$ thymidine. Next, $\left[{ }^{3} \mathrm{H}\right]$ thymidine incorporation was determined by liquid scintillation counting.

\section{Statistical analysis}

The data are presented as the mean values \pm standard error.

\section{RESULTS}

Generation and characterisation of anti-idiotypic antibody to prolactin

Employing the hybridoma technique, a panel of antiidiotypic monoclonal antibodies to PRL was obtained. To determine whether Mab2s that can bind to PRLR on CHOPRLR cells, flow cytometry analysis was performed, and nine mab2s exhibited strong positive signals. Among these, one Mab2 (designed B7) was selected for further characterization as described as below. B7 was classified as an IgG1 isotype using a commercial mouse mAb isotyping kit.

Competitive ELISA was performed to assess whether B7 could mimic a PRL epitope (namely possesses an internal image nature, $A b 2 \beta$ ). The results indicated that PRL could inhibit the interaction between the anti-PRL antibodies and anti-idiotypic monoclonal antibody B7. As illustrated in Figure 1, PRL inhibited polyclonal anti-PRL binding to B7 in a dose-dependent manner, and control antibody showed no effects. Moreover, PRL could also compete with B7 for binding to polyclonal anti-PRL antibodies in a dose-dependent manner (Figure 2). These results indicate that B7 and PRL share a common epitope, which also suggest that $\mathrm{B} 7$ possesses an internal image nature $(\mathrm{Ab} 2 \beta)$.

\section{B7 specifically binds to PRLR on CHO-PRLR}

To demonstrate further whether B7 could specifically bind to PRLR on CHO-PRLR, we performed a competitive receptor-binding assay. As shown in Figure 3, unlabelled PRL displaced ${ }^{125}$ I-PRL from the cells as expected. B7 also

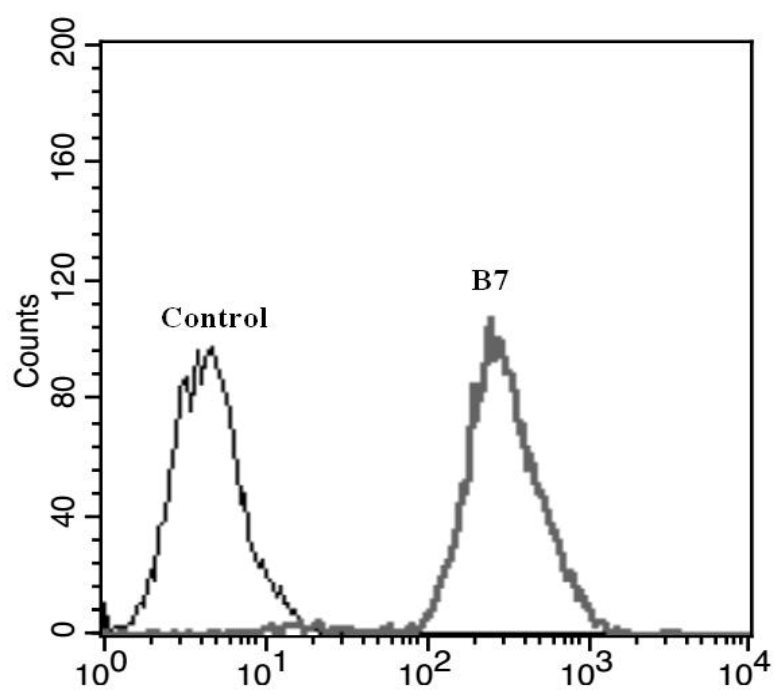

Figure 1. Screen for potential Mab2s that could bind PRLR on CHO-PRLR by FACS. CHO-PRLR cells were pre-treated as described in the materials and methods. The cells were then incubated with negative control media or B7 supernatants for $1 \mathrm{~h}$ at $4^{\circ} \mathrm{C}$. After washing, the cells were then incubated with FITCconjugated secondary antibody for $1 \mathrm{~h}$ in the dark at $4^{\circ} \mathrm{C}$. The cells were then washed, resuspended in FACS buffer and analysed using a FACS Calibur Flow Cytometer. The figures represent at least three independent experiments. PRLR, prolactin receptor; FACS, Fluorescence-activated cell sorting analysis; FITC, fluorescein isothiocyanate.

displaced ${ }^{125} \mathrm{I}-\mathrm{PRL}$ in a dose-dependent manner; however, the control antibody elicited no effects. These results demonstrated that B7 specifically binds to PRLR expressed on target cells.

\section{JAK2-STAT5 signalling pathway induced by $B 7$}

The abovementioned experiments demonstrated that B7 could specifically bind to PRLR. However, it is unclear whether B7 can trigger PRLR-induced intracellular signalling. Therefore, the western-blot was performed to check whether the agonistic effect of B7 exerted on $\mathrm{CHO}$ transfected with PRLR or not could mimic the signal transduction of PRL. As shown in Figure 4, PRL strongly induced phosphorylation of JAK2-STAT5 in CHO-PRLR but not parent CHO cells. Similar to PRL, B7 also activates the JAK2-STAT5 pathway in CHO-PRLR but not parent $\mathrm{CHO}$ cells. However, the control antibody shows no effect.

Next, the kinetics of JAK2-STAT5 activation by B2 or PRL was determined by western-blot analysis in CHOPRLR cells, and representative results are shown in Figure $5 \mathrm{~A}$ and $5 \mathrm{~B}$, respectively. The dose-response of JAK2 activation by either PRL or B7 was similar to each other. PRL or B7 treatment resulted in the rapid phosphorylation of JAK2, and phosphorylation was detectable at $3 \mathrm{nM}$. The maximal activation in response to PRL or B7 was observed between 10 and $20 \mathrm{nM}$ and subsequently began to decline. 
A

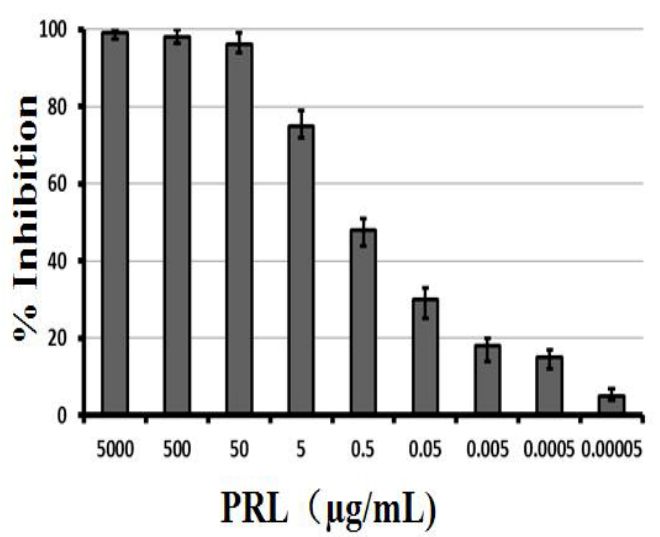

B

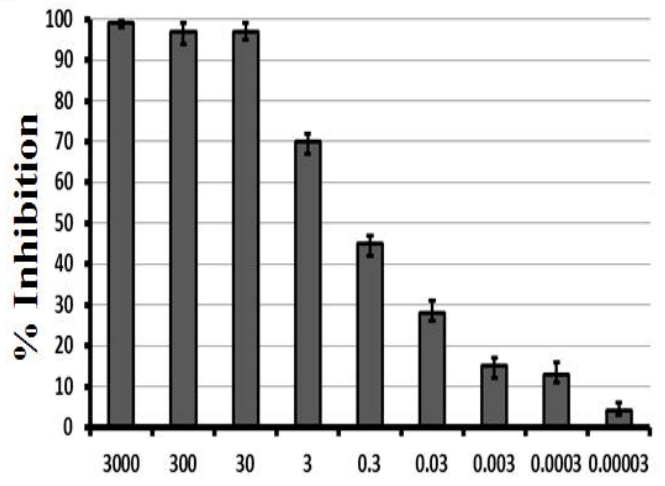

PRL $(\mu \mathrm{g} / \mathrm{mL})$

Figure 2. Competitive ELISA assay. (A) PRL inhibits the binding of rabbit anti-PRL to B7. ELISA plates were coated with $0.5 \mu \mathrm{g}$ of B7$\mathrm{F}(\mathrm{ab}) 2$, and a constant amount of rabbit anti-PRL together with different concentrations of PRL were added. (B) PRL inhibits the binding of B7 to the rabbit anti-PRL. ELISA plates were coated with $0.5 \mu \mathrm{g}$ rabbit anti-PRLR-F(ab')2, and a constant amounts of B7 together with increasing concentrations of PRL were added. Then, the goat anti-rabbit or mouse IgG (Fc fragment-specific)-HRP secondary antibody was added to the wells. The colorimetric reactions were developed using TMB. The results were read at $450 \mathrm{~nm}$ in an automated ELISA plate reader. ELISA, enzyme-linked immunosorbent assays; PRL, prolactin receptor; TMB, tetramethylbenzidine.

In addition, the time courses of JAK2 and STAT5 activation by PRL or B7 were also similar in CHO-PRLR cells. For each stimulator, JAK2 and STAT5 activation was observed as early as $5 \mathrm{~min}$, maximised at 15 to $45 \mathrm{~min}$, and declined dramatically thereafter.

To confirm the agonistic effect of B7 further, we also evaluated JAK2-STAT5 signalling induced by B7 in $\mathrm{Nb} 2$ cells. As shown in Figure 6A and 6B, the dose-response of Jak2 activation by either PRL or B7 was similar to each

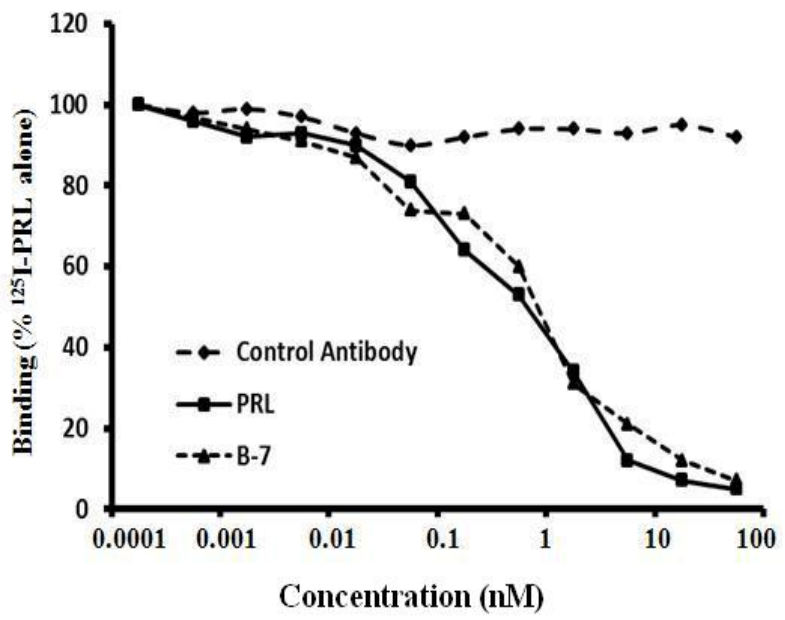

Figure 3. B7 competes with PRL for binding to PRLR on CHOPRLR. The cells were pre-treated as described in the materials and methods. The cells were incubated with the indicated amounts of ${ }^{125}$ I-PRL and various concentrations of unlabelled PRL, B7 or control antibody. After washing, the cells were detached and counted in a gamma counter. The data showed are the mean $\pm \mathrm{SE}$ from three independent experiments. PRL, prolactin receptor; SE, standard error. other. PRL or B7 treatment resulted in the rapid phosphorylation of JAK2, and phosphorylation was detectable at $3 \mathrm{nM}$. The maximal activation in response to PRL or B7 was observed between 10 to $20 \mathrm{nM}$, and subsequently began to decline. In addition, the time courses of JAK2 and STAT5 activation by PRL or B7 were also similar in CHO-PRLR cells. For each stimulator, JAK2 and STAT5 activation was observed as early as $5 \mathrm{~min}$,

PRL B-7 control PRL B-7 control

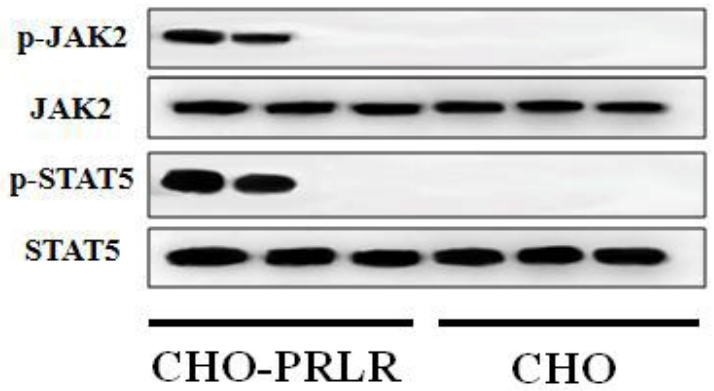

Figure 4. Activation of JAK2-STAT5 signal transduction by B7. The CHO-PRLR cells were pre-treated as described as in the materials and methods. The cells were challenged with PRL, B7 or control antibody $(20 \mathrm{nM})$ for $0.5 \mathrm{~h}$. The CHO-PRLR cells were then solubilised, harvested and concentrated by ultrafiltration. Equal amounts of protein from each treatment was separated by SDS-PAGE and transferred to PVDF membranes. The membranes were detected with the indicated antibodies. The figures represent at least three independent experiments. JAK2-STAT5, Janus kinase-signal transducer and activator of transcription; PRL, prolactin receptor; SDS-PAGE, sodium dodecyl sulfatepolyacrylamide gel electrophoresis; PVDF, polyvinylidene fluoride. 

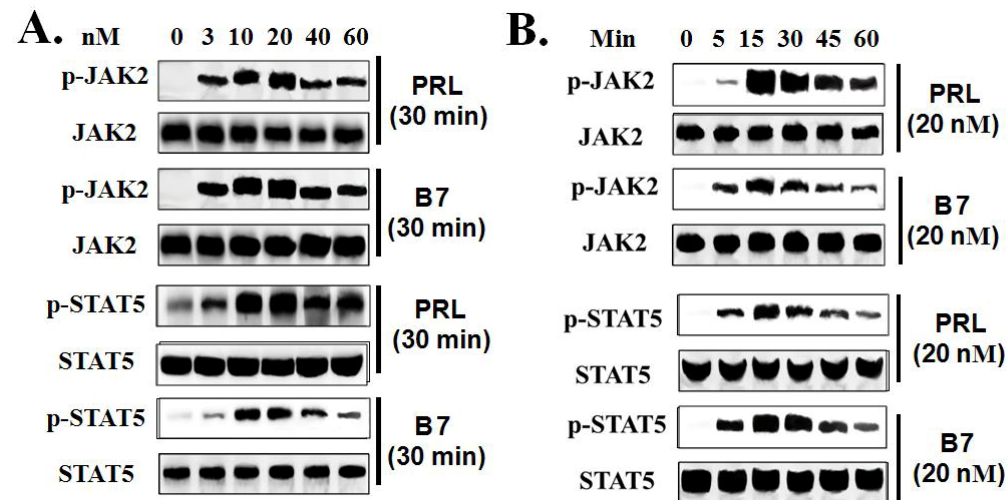

Figure 5. Dose-response and time-course profiles for JAK2-STAT5 phosphorylation induced by B7 in CHO-PRLR cells. (A) Doseresponse of JAK2-STAT5 phosphorylation induced by PRL or B7. The cells were pre-treated as described in the materials and methods. CHO-PRLR were challenged with PRL or B7 (0 to $60 \mathrm{nM})$ for $20 \mathrm{~min}$ at $37^{\circ} \mathrm{C}$. The $\mathrm{CHO}-\mathrm{PRLR}$ cells were then solubilised, harvested and concentrated by ultrafiltration. Equal amounts of protein from each treatment were then subjected to SDS-PAGE and transferred to PVDF membranes. The membranes were probed with anti-p-JAK2 and anti-p-STAT5 antibodies. (B) Time-course of JAK2-STAT5 phosphorylation induced and PRL or B7. The cells were pre-treated as described as in the materials and methods. CHO-PRLR cells were stimulated with $20 \mathrm{nM}$ PRL or B7 for 0 to $60 \mathrm{~min}$ at $37^{\circ} \mathrm{C}$. The CHO-PRLR cells were then solubilised, harvested and concentrated by ultrafiltration. Equal amounts of protein from each treatment were then subjected to SDS-PAGE and transferred to PVDF membranes. The membranes were probed with anti-p-JAK2 and anti-p-STAT5 antibodies. The figures represent at least three independent experiments. JAK2-STAT5, Janus kinase-signal transducer and activator of transcription; PRL, prolactin receptor; SDS-PAGE, sodium dodecyl sulfate-polyacrylamide gel electrophoresis; PVDF, polyvinylidene fluoride.

maximised at 15 to $45 \mathrm{~min}$, and declined dramatically thereafter.

Effect of $\mathrm{B} 7$ on $\mathrm{Nb2}$ and $\mathrm{Ba} / \mathrm{F3}-\mathrm{PRLR}$ cell proliferation

The $\left[{ }^{3} \mathrm{H}\right]$-thymidine incorporation assay was performed to further assess agonistic activity of B7. As shown in Figure $7 \mathrm{~A}$ and $7 \mathrm{~B}$, both $\mathrm{B} 7$ and PRL promoted $\mathrm{Nb} 2$ and $\mathrm{Ba} / \mathrm{F} 3-\mathrm{PRLR}$ cell proliferation in a dose-dependent manner. The maximal proliferation effect of PRL was shown at 1 to $10 \mathrm{nM}(\mathrm{Nb} 2)$ and 1 to $10 \mathrm{nM}(\mathrm{Ba} / \mathrm{F} 3-P R L R)$, and the
A.

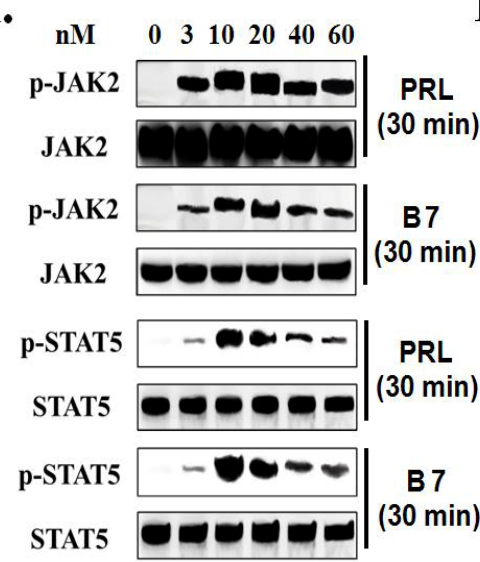

B.

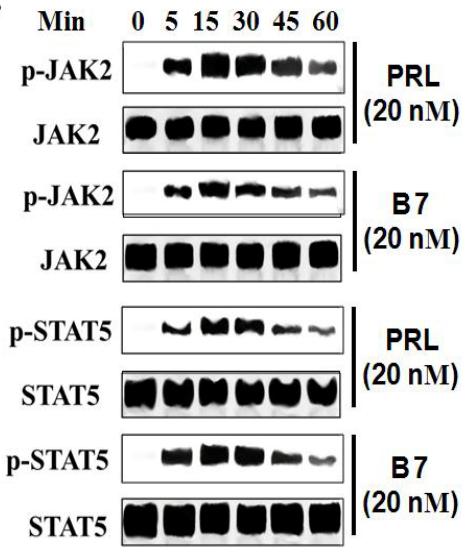

Figure 6. Dose-response and time-course profiles for JAK2-STAT5 phosphorylation induced by B7 in Nb2 cells. (A) Dose-response of JAK2-STAT5 phosphorylation induced by PRL or B7. The cells were pre-treated as described as in the materials and methods. Nb2 cells were then challenged with PRL or B7 $(0$ to $60 \mathrm{nM})$ for $20 \mathrm{~min}$ at $37^{\circ} \mathrm{C}$. The CHO-PRLR cells were then solubilised, harvested and concentrated by ultrafiltration. Equal amounts of protein from each treatment were then subjected to SDS-PAGE and transferred to PVDF membranes. The membranes were probed with anti-p-JAK2 and anti-p-STAT5 antibodies. (B) Time-course of JAK2-STAT5 phosphorylation induced PRL or B7. The cells were pre-treated as described as in the materials and methods. Nb2 cells were then challenged with $20 \mathrm{nM}$ PRL or B7 for 0 to $60 \mathrm{~min}$ at $37^{\circ} \mathrm{C}$. The $\mathrm{Nb} 2$ cells were then solubilised, harvested and concentrated by ultrafiltration. Equal amounts of protein from each treatment were then subjected to SDS-PAGE and transferred to PVDF membranes. The membranes were probed with anti-p-JAK2 and anti-p-STAT5 antibodies. The figures represent at least three independent experiments. JAK2-STAT5, Janus kinase-signal transducer and activator of transcription; PRL, prolactin receptor; SDS-PAGE, sodium dodecyl sulfate-polyacrylamide gel electrophoresis; PVDF, polyvinylidene fluoride. 
maximal proliferation effect of $\mathrm{B} 7$ was shown at 1 to $5 \mathrm{nM}$ $(\mathrm{Nb} 2)$ and 1 to $10 \mathrm{nM}(\mathrm{Ba} / \mathrm{F} 3-\mathrm{PRLR})$, and at higher concentrations, the cell proliferation levels was observed to decline slightly. However, the control antibody exhibits no effect when compared with B7.

\section{DISCUSSION}

In the current study, we produced a monoclonal, antiidiotypic antibody to PRL, named B7, which can serve as a PRL mimic. To the best of our knowledge, this study is the first to report the use of an anti-idiotypic antibody to mimic PRL functions.

In previous studies, the use of an anti-idiotypic antibody strategy to prepare the mimics of cytokine and growth factor has been extensively reported. This approach is based on the immune network theory of Jerne (1974), who proposed that the immune system is a network of interacting idiotypes that is involved in the regulation of immune responses. According to this theory, if animals are immunized with a ligand (e.g., PRL), many anti-ligand (PRL) antibodies will be produced (termed as Ab1).If the antibodies (Ab1) are directed against the receptor-binding sites on the ligand (PRL), then a subpopulation of resulting anti-idiotypic antibodies using Ab1 as immunogens can recognise the same receptor. These $\mathrm{Ab} 2$ antibodies are referred to as Ab2 $\beta$ or "internal images" antibodies. Their classical feature is that the common epitope is shared by the anti-idiotypic antibodies (Ab2 $\beta)$ and the ligand (Lan et al., 2015).

In the present study, a monoclonal anti-idiotypic antibody to PRL (B7) was generated. Through a series of experimental analyses, we demonstrated that B7 can

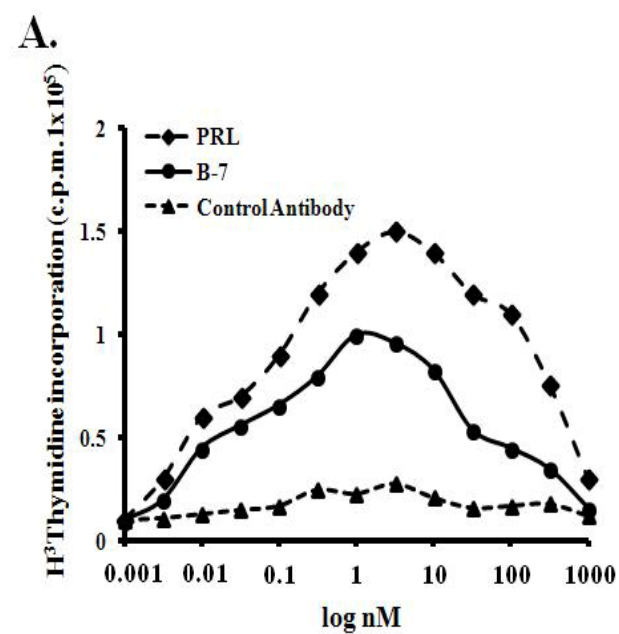

specifically binds to PRLR expressed on target cells. Then, we assessed its biological activities by determining whether it can trigger intracellular signal transduction. It is well known that the JAK2-STAT5 signalling is the most important PRLR-mediated signalling pathway. Therefore, we primarily tested JAK2/STAT5 signalling induced by B7 in this study using western blotting. We found that B7 could activate JAK2-STAT5 signalling in CHO-PRLR and $\mathrm{Nb} 2$ cells, and the dose- and time-dependent response profiles of JAK2-STAT5 activation by B7 (Figures 5 and 6) were similar to those observed for PRL. Furthermore, B7 also can induce $\mathrm{Nb} 2$ cell proliferation (Figure 7). These results indicate that an anti-idiotypic antibody (such as B7) may be suitable as PRL mimics or a PRLR agonist. However, we also found some interesting phenomena, B25 and B19 (another two anti-idiotypic antibody to PRL in the present study) also satisfied the anti-idiotypic criteria based on competition analysis (data not shown), but they showed no or very weak agonistic activity in signalling compared with PRL or B7. The reason for this weak agonistic activity is unclear. We speculate the following: i) they partly mimic the epitope of PRL in the primary and secondary structures; therefore, they do not elicit "active" conformation changes in the receptor compared with PRL; ii) they induce conformational change(s) in the PRLR that do not support activation; iii) they do not satisfy other requirements for PRLR activation.

The use of anti-PRLR antibody as PRL mimic were initially reported by Djiane et al. (1981), who prepared polyclonal antibodies against PRLR, and found that the polyclonal anti-PRLR antibodies were capable of mimicking prolactin action on casein gene expression and on DNA synthesis. However, the mechanism(s) by which

B.

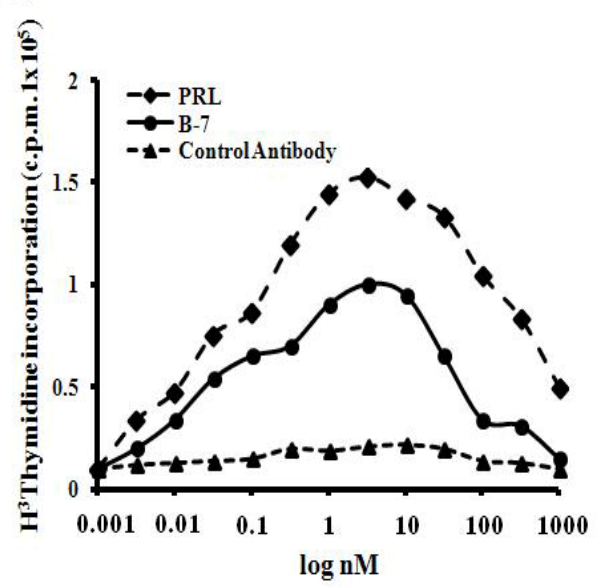

Figure 7. $\mathrm{Nb} 2$ (A) and $\mathrm{Ba} / \mathrm{F} 3-\mathrm{PRLR}$ (B) cell proliferation induced by $\mathrm{B}$ 7. $\mathrm{Nb} 2$ or $\mathrm{Ba} / \mathrm{F} 3-\mathrm{PRLR}$ cells were cultured and pre-treated as described in the materials and methods. The cells were then stimulated with varying concentrations of PRL, B7 or control antibody for 24 h. Then, ligand-stimulated $\mathrm{Nb} 2$ or $\mathrm{Ba} / \mathrm{F} 3-\mathrm{PRLR}$ cells were labelled for $4 \mathrm{~h}$ with $0.5 \mu \mathrm{Ci}$ of $\left[{ }^{3} \mathrm{H}\right]$ thymidine. $\left[{ }^{3} \mathrm{H}\right]$ thymidine incorporation was then determined by liquid scintillation counting. The results are representative of at least three separate experiments. PRLR, prolactin receptor. 
the anti-PRLR antibodies displaying PRL-like activities remains unclear. In the present work, we concentrated our work on intracellular signaling induced by B7, and found that B7 could activate JAK2-STAT5 signaling, and the dose- and time-dependent response profiles of JAK2STAT5 activation by B7 (Figures 5 and 6) were similar to those observed for PRL. It is well known that prolactin exerts its physiological roles mainly via Jak2/STAT5mediated signalling pathway. Therefore, this study may partially reveal the action mechanism(s) of the prolactin's mimics (anti-PRLR antibody, anti-idiotypic antibody), which also suggests that an anti-idiotypic antibody (such as B7) may be an ideal mimic of PRL.

The use of an antibody as a tool to explore the mechanism of hormone receptor activation has been reported. Li et al. (2013) prepared a monoclonal antiidiotypic antibody to $\mathrm{GH}$, called CG-8F, which not only activates growth hormone receptor (GHR) but also shows different intracellular signalling pathway compared with GH. Furthermore, another study from same group reported that a monoclonal anti-GHR antibody, CG-172, also activates a different intracellular signalling pathway compared with $\mathrm{GH}$, and these results led the authors to propose that the antibody is an attractive tool for exploring the mechanism of GHR activation (Lan et al., 2014). Therefore, except for serving as PRL mimics, B7 may have another potential application in which B7 also can be used as an important tool to explore the mechanism(s) of PRLR activation, because until now, the mechanism(s) of PRLR activation have been intensively studied but have not been thoroughly elucidated (Brooks, 2012).

In summary, the current observations indicate that B7 may possess PRL-like bioactivities, which can be used to regulate mammary gland development, milk production and maintenance of lactation. Furthermore, the current findings imply that if domestic animals (such as cows and dairy goats) are immunized with a particular anti-PRL antibody, some special anti-idiotypic antibodies that can mimic PRL will be generated by the animals, which may be useful to increase milk production in cows and dairy goats. Although this work indicates that an anti-idiotypic antibody, B7, may have the potential to become a mimic of PRL, this is only a fundamental and preliminary study in the field. Therefore, we will further evaluate the physiological roles of $\mathrm{B} 7$ in domestic animals in the next step.

\section{CONFLICT OF INTEREST}

We certify that there is no conflict of interest with any financial organization regarding the material discussed in the manuscript.

\section{REFERENCES}

Amit, T., R. J. Barkey, M. Gavish, and M. B. H. Youdim. 1986. Antiidiotypic antibodies raised against anti-prolactin (prl) antibodies recognize the prl receptor. Endocrinology 118:835843.

Bar-Pelled, U., E. Maltz, I. Bruckental, Y. Folman, Y. Kali, H. Gacitua, A. R. Lehrer., C. H. Knigh., B. Robinzon., H. Voet, and H. Tagari. 1995. Relationship between frequent milking or suckling in early lactation and milk production of high producing dairy cows. J. Dairy Sci. 78:2726-2736.

Bole-Feysot, C., V. Goffin, M. Edery, N. Binart, and P. A. Kelly. 1998. Prolactin (PRL) and its receptor: actions, signal transduction pathways and phenotypes observed in PRL receptor knockout mice. Endocr. Rev. 19:225-268.

Brooks, C. L. 2012. Molecular mechanisms of prolactin and its receptor. Endocr. Rev. 33:504-525.

Clevenger, C. V., T. Torigoe, and J. C. Reed. 1994. Prolactin induces rapid phosphorylation and activation of prolactin receptor-associated RAF-1 kinase in a T-cell line. J. Biol. Chem. 269:5559-5565.

Djiane, J., I. Dusanter-Fourt, M. Katoh, and P. A. Kelly. 1985. Biological activities of binding site specific monoclonal antibodies to prolactin receptors of rabbit mammary gland. J. Biol. Chem. 260:11430-11435.

Djiane, J., L. M. Houdebine, and P. A. Kelly. 1981. Prolactin-like activity of anti-prolactin receptor antibodies on casein and DNA synthesis in the mammary gland. Proc. Natl. Acad. Sci. USA. 78:7445-7448.

Dybus, A. 2002. Associations of growth hormone (GH) and prolactin (PRL) genes polymorphisms with milk production traits in Polish Black-and-White cattle. Anim. Sci. Pap. Rep. 20:203-212.

Farmer, C., M. T. Sorensen, and D. Petitclerc. 2000. Inhibition of prolactin in the last trimester of gestation decreases mammary gland development in gilts. J. Anim. Sci. 78:1303-1309.

Feuermann, Y., S. J. Mabjeesh, and A. Shamay. 2004. Leptin affects prolactin action on milk protein and fat synthesis in the bovine mammary gland. J. Dairy Sci. 87:2941-2946.

Freeman, M. E., B. Kanyicska, A. Lerant, and G. Nagy. 2000. Prolactin: Structure, function, and regulation of secretion. Physiol. Rev. 80:1523-1631.

He, F., D. Sun, Y. Yu, Y. Wang, and Y. Zhang. 2006. Association between SNPs within prolactin gene and milk performance traits in Holstein dairy cattle. Asian Australas. J. Anim. 19:1384-1389.

Jerne, N. K. 1974. Towards a network theory of the immune system. Ann. Immunol. 125:373-389.

Knight, C. H. 2001. Overview of prolactin's role in farm animal lactation. Livest. Prod. Sci. 70:87-93.

Lan, H. N., W. Li, Z. L. Fu, Y. H. Yang, T. C. Wu, Y. Liu, H. Zhang, H. Z. Cui, Y. M. Li, P. Hong, J. S. Liu, and X. Zheng. 2014. Differential intracellular signalling properties of the growth hormone receptor induced by the activation of an antiGHR antibody. Mol. Cell. Endocrinol. 390:54-64.

Lan, H. N., H. L. Jiang, W. Li, T. C. Wu, P. Hong, Y. M. Li, H. Zhang, H. Z. Cui, and X. Zhing. 2015. Development and 
characterization of a novel anti-idiotypic monoclonal antibody to growth hormone, which can mimic physiological functions of growth hormone in primary porcine hepatocytes. Asian Australas. J. Anim. Sci. 28:573-583.

Lan, H. N, X. Zheng, M. A. Khan, and S. Li. 2015. Anti-idiotypic antibody: A new strategy for the development of a growth hormone receptor antagonist. Int. J. Biochem. Cell. B. 68:101108.

McLaughlin, C. L., J. C. Byatt, D. F. Curran, J. J. Veenhuizen, M. F. McGrath, F. C. Buonomo, R. L. Hintz, and C. A. Baile. 1997. Growth performance, endocrine, and metabolite responses of finishing hogs to porcine prolactin. J. Anim. Sci. 75:959-967.

Okamura, H., J. Zachwieja, S. Raguet, and P. A. Kelly. 1989. Characterization and Applications of Monoclonal Antibodies to the prolactin receptor. Endocrinology 124:2499-2508.
Ramos, A. M., C. A. P. Matos, P. A. Russo-Almeida, C. M. V. Bettencourt, J. Matos, A. Martins, C. Pinheiro, and T. RangelFigueiredo. 2009. Candidate genes for milk production traits in Portuguese dairy sheep. Small Rumin. Res. 82:117-121.

Reddy, I. J., C. G. David, and K. Singh. 2005. Relationship between Intersequence pauses, laying persistency and concentration of prolactin during the productive period in white Leghorn hens. Asian Australas. J. Anim. Sci. 18:686-691. Rui, H., J. J. Lebrun, R. A. Kirken, P. A. Kelly, and W. L. Farrar. 1994. JAK2 activation and cell proliferation induced by antibody-mediated prolactin receptor dimerization. Endocrinology 135:1299-1306.

Tygesen, M. P., M. O. Nielsen, P. Nørgaard, H. Ranvig, A. P. Harrison, and A. H. Tauson. 2008. Late gestational nutrient restriction: Effects on ewes' metabolic and homeorhetic adaptation, consequences for lamb birth weight and lactation performance. Arch. Anim. Nutr. 62:44-59. 